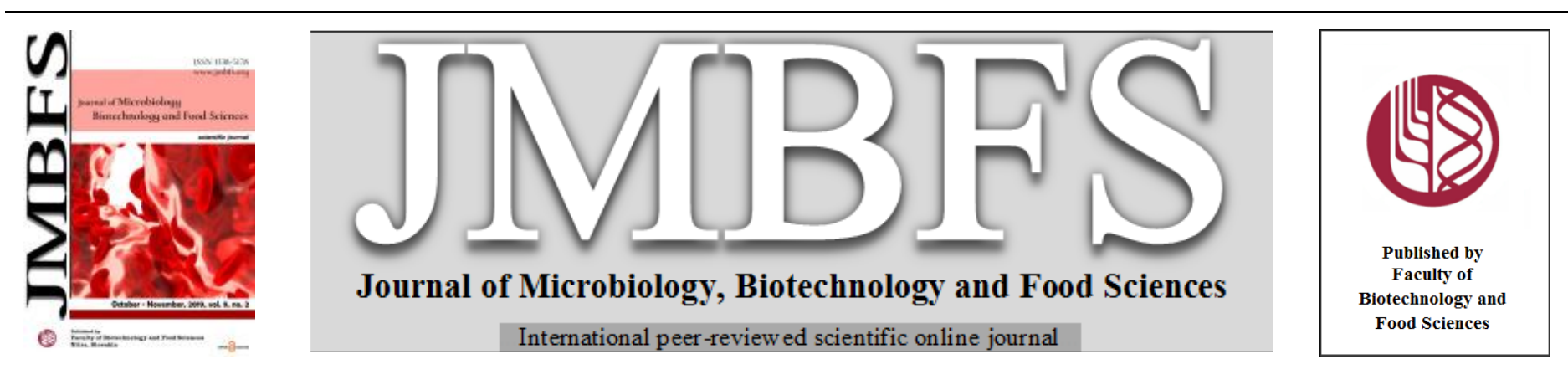

\title{
CHARACTERIZATION OF ANTIMICROBIAL SUBSTANCE WITH ANTIBIOFILM ACTIVITY FROM Pediococcus acidilactici
}

\author{
Garima Sharma, Haney Gupta, Shweta Dang, Sanjay Gupta, Reema Gabrani*
}

Address(es):

Department of Biotechnology, Jaypee Institute of Information Technology, A-10, Sector-62, NOIDA, 201309, India

*Corresponding author: reema.gabrani@jiit.ac.in

doi: 10.15414/jmbfs.2020.9.5.979-982

\section{ARTICLE INFO}

Received 1. 7. 2018

Revised 19. 11. 2019

Accepted 19. 11. 2019

Published 1. 4. 2020

Regular article open $\mathcal{O}$ access

\begin{abstract}
Objective: The aim of the current study was to isolate and identify the strain having broad spectrum antibacterial and antibiofilm activity and characterize its antimicrobial substance.

Methods: Lactic acid bacteria isolated from the raw milk of Indian goat species Babri and Sirohi (Capra aegagrus hircus) were screened for antibacterial activity against Staphylococcus epidermidis, Micrococccus luteus, Pseudomonas fluorescens and Escherichia coli. The selected strains were also analysed for anti-biofilm activity on S. epidermidis. The potential bacterial strain was characterized at molecular level by $16 \mathrm{~S}$ rDNA sequencing. The antimicrobial substance produced by P. acidilactici was precipitated by $90 \%$ ammonium sulphate and subsequently ultra filtered. It was analysed for size, stability under various $\mathrm{pH}$, temperature, chemicals and enzymatic conditions. Its mechanism of killing was determined by ML35p assay and scanning electron microscopy (SEM).

Results: The 16S rDNA sequence of the potential isolate, possessing broad spectrum antibacterial activity and antibiofilm activity against S. epidermidis, was deposited to Genbank under accession no. KP671843 and was identified as Pediococcus acidilactici. The partially purified bacteriocin ran at approximately $3500 \mathrm{Da}$ on tris- tricine SDS-PAGE and showed antibacterial activity against $S$. epidermidis by In-gel assay. Partially purified bacteriocin was stable at wide $\mathrm{pH}$ and high temperature and also to the treatment of lipase, amylase, catalase and various detergents/organic solvents. However, it was sensitive to proteolytic enzymes indicating its proteinaceous nature. Results of membrane permeability assay revealed that the bacteriocin targets bacterial cell membrane as its bactericidal action.

Conclusion: The bacteriocin from P. acidilactici has the potential to be used as broad spectrum antibacterial and antibiofilm agent.
\end{abstract}

Keywords: Bacteriocin; Membrane permeability; SEM; Staphylococcus epidermidis

\section{INTRODUCTION}

Bacteriocins are short chain peptides which are ribosomally synthesized by bacteria and are found to be active against narrow as well as broad spectrum bacteria. Previous studies showed the use of bacteriocin in food preservation but recently biomedical applications have also come to forte (Yang, 2014).

Due to entitlement of "Generally Recognised as Safe (GRAS)" by United States Food and Drug Administration (US FDA), lactic acid bacteria (LAB) are gaining interest as source of bacteriocin. LAB are known for potential source of bacteriocinogenic bacteria as well as bacteriocin isolation but most of the bacteriocins have been poorly characterized (Alvarez-Sieiro, 2016) . LAB are found in varied sources including dairy products, plant materials, fermented products, animals and humans (Mokoena, 2017). LAB have been extensively studied as food preservative agents whereas their role in medical biotechnology is still underexplored.

Bacteriocins are small peptides synthesized by bacteria including LAB which help them to protect mainly against closely related species. Bacteriocins are known for their cationic nature and have varied size, origin, mechanism of action and differential antimicrobial activity. Few studies have shown broad spectrum inhibition by bacteriocin which could be beneficial to restrict human pathogens (Chikindas, 2018) . Bacteriocins from LAB have been classified as major classes. Class I bacteriocin or lantibiotics have unusual amino acids which provide them stability. Bacteriocins belonging to class II are small unmodified hydrophobic peptides which are very diverse. They have been further classified as IIa having antilisterial activity and include pediocin or similar bacteriocins. Class IIb execute their action by two peptides, class IIc are cyclic and IId belong to other peptides. Class III peptides are generally large and heat sensitive proteins (Perez, 2014). The search for new bacteriocins with a wide range of antibacterial activity, especially against the biofilm and antibiotic resistant strains is very much required.

The current study was undertaken to isolate the bacteria producing antimicrobial substance from goat milk of Indian goat species as it has been reported for rich source of indigenous microflora. The current study was designed to isolate different microbes which are able to produce antimicrobial substances from raw goat milk using de Man, Rogosa and Sharpe Agar (MRS) agar plates as selective medium. The isolate having broad antimicrobial activity against chosen indicator organisms as well as possessing antibiofilm activity was selected for molecular characterization. The antimicrobial substance from selected strain was partially purified and characterized.

\section{MATERIALS AND METHODS}

\section{Bacterial strains and growth conditions}

Staphylococcus epidermidis (MTCC No. 435), Escherichia coli (MTCC No. 443), Micrococcus luteus (MTCC No. 106) and Pseudomonas fluorescens (MTCC No. 2421) from Microbial Type Culture Collection (MTCC), Chandigarh were used in the current study. Bacteria were grown in nutrient broth at $37^{\circ} \mathrm{C}$ for 16-18 hours. ML-35p E. coli strain was kindly gifted by Dr. Dinkar Sahal from The International Centre for Genetic Engineering and Biotechnology, New Delhi, India.

\section{Isolation of antimicrobial substance producing bacteria from goat milk}

Milk of Indian goat breeds named Babri and Sirohi (Capra aegagrus hircus) was collected from locations Jodhpur (Rajasthan), Noida (Uttar Pradesh) and Greater Noida (Uttar Pradesh) and collected samples were processed same day.

\section{Inhibition spectrum of cell free supernatant of bacterial strains}

Antimicrobial assay was performed by agar well diffusion method. The fresh secondary culture of bacterial strains were diluted to $1 \times 10^{6} \mathrm{cfu} / \mathrm{ml}$ and plated on nutrient agar. Cell free supernatant (CFS) was collected by centrifuging overnight grown culture of bacterial isolates at $10,000 \mathrm{~g} / 15 \mathrm{~min} / 4^{\circ} \mathrm{C} .10 \mu 1$ of CFS was poured in agar well and incubated at $37^{\circ} \mathrm{C}$ for $16 \mathrm{~h}$ and zone of inhibition was measured according to the CLSI guidelines (Sharma, 2018). Each experiment was repeated thrice in triplicates. 


\section{Determination of activity unit AU/ml}

The highest dilution of CFS that gave a visible zone of inhibition multiplied by the dilution factor was considered as activity unit per $\mathrm{ml} .1 \times 10^{6} \mathrm{cfu} / \mathrm{ml} S$ epidermidis was treated with 1:2- 1:128 dilutions of the CFS from each isolate and incubated at $37^{\circ} \mathrm{C}$ for $16-18 \mathrm{~h}$

\section{Antibiofilm activity of cell free supernatant}

The antibiofilm activity of CFS was analysed against the preformed $S$. epidermidis biofilm and also on its biofilm formation as reported by Sharma et al( Sharma, 2016).

Molecular characterization and phylogenetic analysis of 16 S rDNA sequence of potential strain

The genomic DNA of bacterial strain was isolated and16S rDNA region was amplified using universal primers [7] and sequenced. The sequence obtained was submitted to Genbank (accession no. KP671843). The phylogenetic tree of 16S rDNA sequence of $P$. acidilactici strain GAM218 was constructed with other Pediococcus species using CLUSTAL W software.

Purification, molecular weight determination and agar overlay assay of antimicrobial substance

The antimicrobial substance from CFS of GAM218 was precipitated by $70-90 \%$ ammonium sulphate in the increment of $10 \%$. The obtained precipitate was dissolved in $0.1 \mathrm{M}$ Tris- $\mathrm{Cl}$ buffer $\mathrm{pH} 7.0$ and salt removal was done by passing through $3 \mathrm{kDa}$ ultra membrane filter. Molecular weight of purified fraction was analysed on $15 \%$ tricine SDS PAGE gel. Agar overlay assay was performed for determining the location of antimicrobial substance in the gel. The gel was washed, placed on solidified nutrient agar plate and was overlayed with nutrient soft agar seeded with $S$. epidermidis and E. coli separately. The plate was incubated at $37^{\circ} \mathrm{C}$ for $18 \mathrm{~h}$.

\section{Stability of antimicrobial substance at different $\mathrm{pH}$, temperature and} chemicals

The response of $\mathrm{pH}$ (2.0-12.0 at interval of 2) on antibacterial activity of purified sample was measured as discussed in Batdorj et al. (Bardorj, 2006). The effect of temperature on activity of purified sample was determined at $30^{\circ} \mathrm{C}-100^{\circ} \mathrm{C}$ at interval of $10^{\circ} \mathrm{C}$ for $1 \mathrm{hr}$ and autoclaving at $121^{\circ} \mathrm{C}$ for $20 \mathrm{~min}$. The effect of chemicals EDTA, urea, $\mathrm{NaCl}$, benzene, ethyl alcohol, DMSO at $10 \%$ on antimicrobial activity was analysed after incubating for $1 \mathrm{hr}$ at $37^{\circ} \mathrm{C}$. Antibacterial activity of CFS was determined after treating with various enzymes i.e. proteinase $\mathrm{K}$, pepsin, papain, trypsin, catalase, lipase, amylase and lysozyme. The CFS samples were treated at $37^{\circ} \mathrm{C}$ for $1 \mathrm{~h}$ with $1 \mathrm{mg} / \mathrm{ml}$ final concentrations of enzyme and mixture was boiled for $10 \mathrm{~min}$ to inactivate the enzyme. The $S$. epidermidis was chosen as indicator organism for measuring residual antibacterial activity.

\section{ML-35p membrane permeability assay}

Genetically engineered ML-35p E. coli, which has been designed for observing permeability across the membranes, was used in the current study. The protoco followed is as discussed by Sharma et al. (Sharma, 2014). The overnight grown culture was pelleted down followed by washing in phosphate buffer, $\mathrm{pH}$ 7.4. The culture was diluted in incubation buffer to $1 \times 10^{6} \mathrm{cfu} / \mathrm{ml}$ concentration and mixed with $2.5 \mathrm{mM}$ ortho-nitrophenyl- $\beta$-galactoside (ONPG) along with purified bacteriocin. The absorbance was taken at $420 \mathrm{~nm}$ in spectrophotometer (Shimadzu, Japan). SDS $0.1 \%$ was used for complete breakdown of bacterial cell wall and selected as positive control.

\section{Scanning electron microscopy}

The mode of action of purified bacteriocin on $E$. coli cells was visualized by scanning electron microscopy (SEM). The exponentially grown cells with OD 0.2 at $600 \mathrm{~nm}$ were incubated with the purified bacteriocin at $37^{\circ} \mathrm{C}$ for $20 \mathrm{hr}$. The treated bacterial cells were centrifuged and washed with $1 \mathrm{mM}$ phosphate buffer saline PBS at $\mathrm{pH}$ 7. The samples were fixed in $8 \%$ glutaraldehyde followed by gradual dehydration. The morphological changes were visualized under JEOL JSM-7001F SEM (Chopra, 2015)

\section{RESULTS AND DISCUSSION}

\section{Broad spectrum screening of cell free supernatant (CFS)}

India is known as worldwide goat milk producer and has been reported for several indigenous species of goat (Aziz, 2010, Joshi, 2004). Goat milk was selected as a source for bacteriocinogenic bacterial strains as it has been reported as source for diverse bacteria especially LAB.

The collected milk samples were spread plated on MRS agar plate and bacterial strains were isolated by serial dilution method. Obtained isolates were checked for antimicrobial activity against $S$. epidermidis, potential isolates with $>90 \%$ activity was selected and additionally tested for broad spectrum activity against P. fluorescens (MTCC No. 2421), M. luteus (MTCC No. 106) and E. coli (MTCC No. 443). Both Gram-positive and Gram-negative strains showed different sensitivity against CFS of selected isolates. Two milk isolates named GAM109 and GAM218 inhibited biofilm formation and also disrupted $>90 \%$ of the established biofilm of $S$. epidermidis (Table 1). Bacteria GAM218 showed the highest $400 \mathrm{AU} / \mathrm{ml}$ and also displayed $\geq 90 \%$ growth inhibition against all the chosen indicator organisms and biofilm, so it was selected for molecular characterization and bacteriocin purification. Previously reported studies showed the screening criteria of bacteriocinogenic LAB are mainly based on the antimicrobial activity against closely related species (Yang, 2012, El-Shafei, 2000). There are very few systematic studies which have focused on isolating strains having broad spectrum as well as anti-biofilm activity.

\section{Molecular identification of potential strain}

The strain (GAM218) was identified as Pediococcus acidilactici strain by $16 \mathrm{~S}$ rDNA sequencing. The $16 \mathrm{~S}$ partial sequence was deposited to GenBank (accession no. KP671843). P. acidilactici GAM218 showed 99.1\% sequence similarity with other reported sequences of $P$. acidilactici. The phylogenetic tree of amplified sequence of $16 \mathrm{~S}$ rDNA of $P$. acidilactici GAM218 and fourteen different Pediococcus species was constructed using CLUSTAL W software (Fig.

1). MRS agar being selective medium contains acetate salts which allows the growth of LAB whereas restrict the growth of competing bacteria.

Pediococcus sp. is one of the principal LAB and most of its bacteriocins belong to second class in LAB classification (Papagianni, 2009). The bacteriocins belonging to this group are known to have antilisterial activity. Pediocin like peptides mainly isolated from $P$. acidilactici are mostly effective against Grampositive bacteria (Rdriguez, 2002).

Pediocin like bacteriocins produced by different LAB, Streptococcus equines, $P$. acidilactici, Pediococcus pentosaceus, Lactobacillus plantarum, Enterococcus faecium, have been reported to show varied antibacterial spectrum in comparison with pediocin PA-1 (Devi, 2011).

Table 1 Antimicrobial and antibiofilm activity of goat milk isolates against broad spectrum microflora

\begin{tabular}{|c|c|c|c|c|c|c|c|c|}
\hline $\begin{array}{l}\text { S. } \\
\text { no. }\end{array}$ & Isolates & $\begin{array}{l}\% \text { inhibition } \\
\text { against } E \text {. coli }\end{array}$ & $\begin{array}{l}\% \text { inhibition } \\
\text { against } \\
P . \text { fluorescens } \\
\end{array}$ & $\begin{array}{c}\text { \% inhibition } \\
\text { against } \\
\text { M. luteus } \\
\end{array}$ & $\begin{array}{l}\% \text { inhibition } \\
\text { against } \\
\text { S. epidermidis } \\
\end{array}$ & $\begin{array}{l}\text { \% inhibition for } \\
\text { S. epidermidis } \\
\text { biofilm }\end{array}$ & $\begin{array}{c}\% \text { disruption of } \\
\text { preformed biofilm } \\
\text { of S. epidermidis }\end{array}$ & $\mathbf{A U} / \mathbf{m l}$ \\
\hline 1 & GAM 102 & $81.23 \pm 0.3$ & $82.29 \pm 0.9$ & $84.3 \pm 0.8$ & $95.03 \pm 0.4$ & $45.3 \pm 0.6$ & $37.29 \pm 0.5$ & 400 \\
\hline 2 & GAM 108 & $71.19 \pm 0.8$ & $82.27 \pm 0.5$ & $81.50 \pm 0.6$ & $99.0 \pm 0.9$ & $67.29 \pm 0.7$ & $25.28 \pm 0.7$ & 80 \\
\hline 3 & GAM 109 & $83.14 \pm 0.7$ & $92.39 \pm 0.9$ & $82.16 \pm 0.8$ & $96.04 \pm 0.2$ & $96.34 \pm 0.5$ & $93.41 \pm 0.3$ & 400 \\
\hline 4 & GAM 111 & $79.31 \pm 0.9$ & $77.64 \pm 0.4$ & $79.28 \pm 0.5$ & $96.32 \pm 0.5$ & $67.7 \pm 0.3$ & $23.12 \pm 0.7$ & 80 \\
\hline 5 & GAM 113 & $68.56 \pm 0.7$ & $78.39 \pm 0.3$ & $79.87 \pm 0.5$ & $94.75 \pm 0.17$ & $74.39 \pm 0.8$ & $13.63 \pm 0.4$ & 80 \\
\hline 6 & GAM 201 & $89.12 \pm 0.8$ & $90.39 \pm 0.7$ & $90.41 \pm 0.6$ & $93.01 \pm 0.8$ & $84.51 \pm 0.4$ & $71.16 \pm 0.5$ & 80 \\
\hline 7 & GAM 203 & $69.71 \pm 0.9$ & $75.83 \pm 0.4$ & $81.13 \pm 0.7$ & $95.6 \pm 0.4$ & $74.19 \pm 0.8$ & $46.29 \pm 0.5$ & 80 \\
\hline 8 & GAM 206 & $74.61 \pm 0.9$ & $76.41 \pm 0.6$ & $83.60 \pm 0.5$ & $91.5 \pm 0.3$ & $56.61 \pm 0.4$ & $18.50 \pm 0.7$ & 80 \\
\hline 9 & GAM 209 & $69.4 \pm 0.1$ & $79.34 \pm 0.7$ & $73.63 \pm 0.5$ & $95.2 \pm 0.9$ & $54.73 \pm 0.1$ & $26.22 \pm 0.4$ & 80 \\
\hline 10 & GAM 211 & $73.18 \pm 0.6$ & $83.34 \pm 0.7$ & $82.31 \pm 0.9$ & $94.1 \pm 0.6$ & $81.21 \pm 0.4$ & $37.91 \pm 0.5$ & 80 \\
\hline 11 & GAM 218 & $95.64 \pm 0.7$ & $95.13 \pm 0.4$ & $96.13 \pm 0.5$ & $95.06 \pm 0.4$ & $95.17 \pm 0.6$ & $95.26 \pm 0.2$ & 400 \\
\hline 12 & GAM 219 & $87.63 \pm 0.3$ & $83.19 \pm 0.6$ & $90.31 \pm 0.2$ & $95.08 \pm 0.7$ & $81.29 \pm 0.7$ & $68.93 \pm 0.5$ & 160 \\
\hline
\end{tabular}


The $90 \%$ ammonium sulfate precipitate of the CFS obtained from overnight culture of $P$. acidilactici GAM218 showed antimicrobial activity against $S$ epidermidis and $E$. coli whereas the other ammonium sulphate fractions did not exhibit any antimicrobial activity. The bacteriocin after purification displayed molecular weight $\leq 3.5 \mathrm{kDa}$ on the acrylamide gel. Correspondingly the bacteriocin elicited the zone of inhibition on S. epidermidis (Fig. 2) and E. coli (data not shown) as demonstrated by agar overlay assay. The results clearly attributed the antimicrobial activity to the partially purified bacteriocin. Pediocin PA-1 and its related peptides have molecular weight of $4.6 \mathrm{kDa}$. These peptides do not inhibit the growth of $E$. coli cells which indicates that bacteriocin GAM218 is different as compared to pediocin like peptides (Devi, 2011).

A non-pediocin peptide produced by $P$. pentosaceus was shown to have molecular weight of $1.7 \mathrm{kDa}$ which restricted the growth of broad range of indicator organisms indicating the diversity in bacteriocin produced by various Pediococcus strains (Singh, 2014).

$\mid \begin{aligned} & \text { Pediococcus lolii } \\ & \text { Pediococcus } \mathrm{sp} . \\ & \text { Pediococcus } \\ & \text { Pediococcus } \\ & \text { Pediococcus } \\ & \text { Pediococcus } \mathrm{sb} . \\ & \text { Pediococcus lolii } \\ & \text { Pediococcus } \\ & \text { Pediococcus } \\ & \text { Pediococcus } \\ & \text { Pediococcus acidilactici GAM218 }\end{aligned}$

E. $\operatorname{coli}(\mathrm{J} 01695)$

0.2

Figure 1 Phylogenetic tree of $P$. acidilactici KP671843 with closely related bacterial species; constructed by neighborhood joining method. The scale bar represents 0.2 substitutions per nucleotide position

Purification, molecular weight determination and agar overlay assay of antimicrobial substance

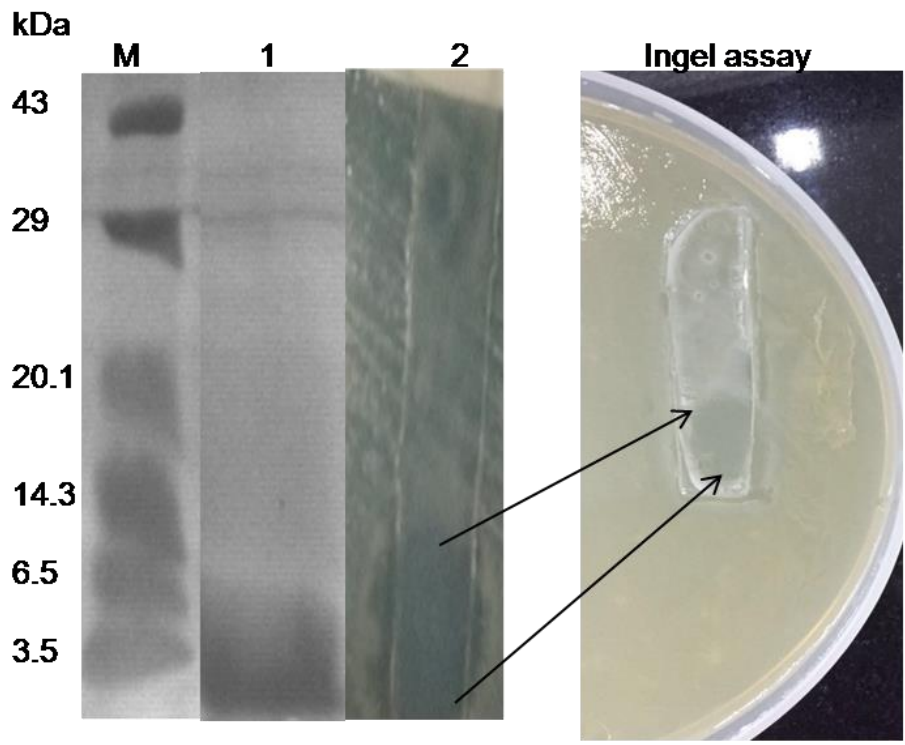

Figure 2 Molecular weight determination and in situ gel activity of the partially purified bacteriocin from, $P$. acidilactici GAM218 by tricine SDS-PAGE. Mlow range molecular weight marker (Fermentas), Lane 1: Partially purified bacteriocin run on SDS-PAGE, Lane 2: Antibacterial activity of partially purified bacteriocin detected in situ on soft agar assay

Effect of pH, temperature and chemicals on stability of antimicrobial substance
Characterization results revealed the loss of antimicrobial activity after treating with protein degrading enzymes proteinase $\mathrm{K}$, pepsin, papain, and trypsin which points to its proteinaceous nature. The bacteriocin remained unaffected by lysozyme, lipase, and amylase which clearly overrule the role of any lipid and carbohydrate moiety for its antimicrobial activity. The partially purified bacteriocin remained stable at wide range of $\mathrm{pH}$ and temperature (Table 2). Moreover, the activity of bacteriocin was not altered in the presence of certain chemicals commonly used for preservation or storage. The literature supports that due to the presence of unusual amino acids, bacteriocins of class I remain stable at extreme $\mathrm{pH}$ range as well as temperature (Drider 2006). The class IIa bacteriocins are stable at varied temperature and $\mathrm{pH}$ but they do lose their activity at extreme $\mathrm{pH}$ and temperature. These bacteriocins are strengthened by disulfide bond and $\alpha$ helices at C-terminal end (Rios, 2017). Bacteriocin GAM218 may belong to lantibiotic class due to its stability under extreme conditions. Moreover, the size and broad spectrum antimicrobial profile of bacteriocin GAM218 indicates that it does not belong to class IIa.

Table 2 The effect of various factors on antimicrobial activity of bacteriocin isolated from $P$. acidilactici GAM218 on S. epidermidis

Stability

Activity of bacteriocin-GAM 218

Temperature $30^{\circ} \mathrm{C}-100^{\circ} \mathrm{C}$ for $1 \mathrm{~h}$ and $121^{\circ} \mathrm{C}$ for $20 \mathrm{~min}$

pH 2-12

Enzymes $1 \mathrm{mg} \cdot \mathrm{ml}^{-1}$ (Proteinase K, Pepsin, Papain,

Trypsin)

Enzymes $1 \mathrm{mg} \cdot \mathrm{ml}^{-1}$ (Catalase, Lipase, Amylase,

Lysozyme)

Chemicals $10 \%$ ( EDTA, Urea, NaCl, Benzene, Ethyl alcohol, DMSO)

Note:(+) presence and (-) absence of antimicrobial activity

\section{Membrane permeability Assays}

E. coli ML35p, genetically engineered bacteria, is being altered to express cytoplasmic $\beta$-galactosidase. Simultaneously it is modified so that it is not able to produce lactose permease (Epand, 2010). The compounds which alter the cell membrane permeability will result in the seepage of $\beta$-galactosidase. The conversion of ortho-nitrophenyl- $\beta$-galactoside (ONPG) to o-nitrophenol (a chromogenic substance), in the presence of antimicrobial substance by the secreted cytoplasmic $\beta$-galactosidase, can be measured at $420 \mathrm{~nm}$. E. coli cells treated with partially purified bacteriocin have shown enhanced membrane permeability supported by the increase in absorbance (Fig. 3). The change after treating with bacteriocin was comparable to the cells treated with $0.1 \%$ SDS used as positive control.

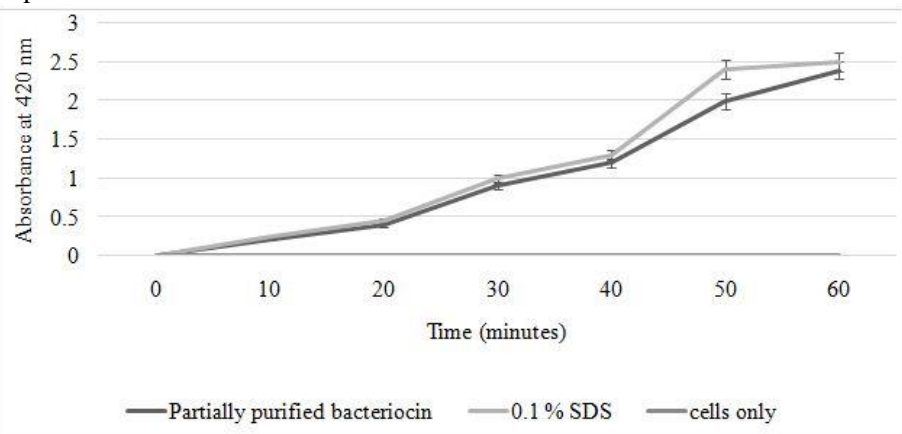

Figure 3 The effect of partially purified bacteriocin on permeabilization of inner membrane of $E$. coli ML35p. The cells treated with $0.1 \%$ SDS and cells without any treatment were considered as positive and negative control, respectively

Effect of partially purified bacteriocin on the bacterial cell membrane was visualized by SEM. E. coli cells as control without any treatment demonstrates intact cell membrane (Fig. 4a). The distorted morphology of bacterial cells treated with partially purified bacteriocin was clearly visible in Fig. 4b. It indicates that the pore formation could be the possible mechanism for bacterial cell death. Studies have revealed that most bacteriocins from LAB act on the bacterial cell membrane as their mechanism of cell killing (Cotter, 2005, Devi, 2014). 

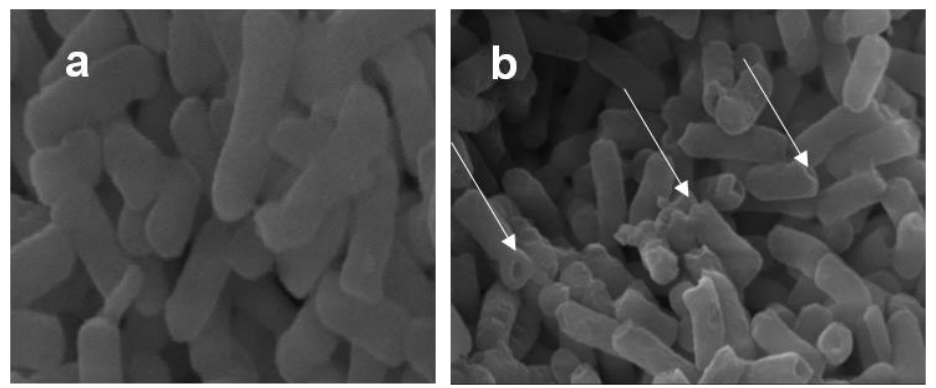

Figure 4 Images of planktonic cells of $E$. coli as viewed under SEM (a) untreated (b) After treatment with partially purified bacteriocin. Arrow indicates damaged membrane

\section{CONCLUSION}

The study was designed to explore unsurveyed source for isolation of potential bacteriocinogenic bacteria having both antimicrobial as well as antibiofilm activity.

The study identified $P$. acidilactici GAM218 as the potential bacterial isolate possessing broad spectrum antimicrobial activity. Bacteriocin exhibited both biofilm inhibition and disruption activity against $S$. epidermidis. The partially purified bacteriocin form $P$. acidilactici GAM218 showed molecular weight of approximately $3.5 \mathrm{kDa}$, having antimicrobial activity at the same location as confirmed by in situ gel assay. The antimicrobial substance from P. acidilactici GAM218 was determined to be proteinaceous in nature with stable antimicrobial activity at wide range of temperature and $\mathrm{pH}$. The mode of action determined by membrane permeability assay as well as scanning electron microscopy confirmed that partially purified bacteriocin targeted bacterial cell membrane as its mechanism of killing.

\section{CONFLICT OF INTEREST}

The authors declare that they have no conflict of interest in the publication

\section{REFERENCES}

Alvarez-Sieiro, P., Montalbán-López, M., Mu, D., \& Kuipers, O. P. (2016) Bacteriocins of lactic acid bacteria: extending the family. Applied Microbiology and Biotechnology, 100(7), 2939-2951. http://dx.doi.org/10.1007/s00253-0167343-9

Aziz, M. A. (2010). Present status of the world goat populations and their productivity. Lohmann Information, 45(2),

https://www.scribd.com/document/92912193/Present-Status-of-the-World-Goat-

Populations-and-Their-Productivity

Batdorj, B., Dalgalarrondo, M., Choiset, Y., Pedroche, J., Metro, F., Prévost, H. \& Haertlé, T. (2006). Purification and characterization of two bacteriocins produced by lactic acid bacteria isolated from Mongolian airag. Journal of Applied Microbiology, 101(4), 837-848. http://dx.doi.org/10.1111/j.13652672.2006.02966.x

Chikindas, M. L., Weeks, R., Drider, D., Chistyakov, V. A., \& Dicks, L. M. (2018). Functions and emerging applications of bacteriocins. Current Opinion in Biotechnology, 49, 23-28. http://dx.doi.org/10.1016/j.copbio.2017.07.011

Chopra, L., Singh, G., Jena, K. K., \& Sahoo, D. K. (2015). Sonorensin: a new bacteriocin with potential of an anti-biofilm agent and a food biopreservative. Scientific

13412. http://dx.doi.org/10.1038/srep13412

Cotter, P. D., Hill, C., \& Ross, R. P. (2005). Food microbiology: bacteriocins: developing innate immunity for food. Nature Reviews Microbiology, 3(10), 777 http://dx.doi.org/10.1038/nrmicro1273

Devi, S. M., \& Halami, P. M. (2011). Detection and characterization of pediocin PA-1/AcH like bacteriocin producing lactic acid bacteria. Current Microbiology, 63(2), 181-185. http://dx.doi.org/10.1007/s00284-011-9963-8

Devi, S. M., Ramaswamy, A. M., \& Halami, P. M. (2014). In situ production of pediocin PA-1 like bacteriocin by different genera of lactic acid bacteria in soymilk fermentation and evaluation of sensory properties of the fermented soy curd. Journal of Food Science and Technology,51(11), 3325-3332. http://dx.doi.org/10.1007/s13197-012-0870-1

Drider, D., Fimland, G., Héchard, Y., McMullen, L. M., \& Prévost, H. (2006). The continuing story of class IIa bacteriocins. Microbiology and Molecular Biology Reviews70(2), 564-582. http://dx.doi.org/10.1128/MMBR.00016-05

El-Shafei, H. A., El-Sabour, H. A., Ibrahim, N., \& Mostafa, Y. A. (2000) Isolation, screening and characterization of bacteriocin-producing lactic acid bacteria isolated from traditional fermented food. Microbiological Research, 154(4), 321-331. http://dx.doi.org/10.1016/s0944-5013(00)80006-3 Epand, R. F., Pollard, J. E., Wright, J. O., Savage, P. B., \& Epand, R. M. (2010). Depolarization, bacterial membrane composition, and the antimicrobial action of ceragenins. Antimicrobial Agents and Chemotherapy, 54(9), 3708-3713. http://dx.doi.org/10.1128/AAC.00380-10
Joshi, M. B., Rout, P. K., Mandal, A. K., Tyler-Smith, C., Singh, L., \& Thangaraj, K. (2004). Phylogeography and origin of Indian domestic goats. Molecular Biology and Evolution, 21(3), 454-462. http://dx.doi.org/10.1093/molbev/msh038

Mokoena, M. P. (2017). Lactic acid bacteria and their bacteriocins: Classification, biosynthesis and applications against uropathogens: A minireview. Molecules, 22(8), 1255. http://dx.doi.org/10.3390/molecules22081255

Papagianni, M., \& Anastasiadou, S. (2009). Pediocins: The bacteriocins of Pediococci. Sources, production, properties and applications. Microbial Cell Factories, 8(1), 3. http://dx.doi.org/10.1186/1475-2859-8-3

Perez, R. H., Zendo, T., \& Sonomoto, K. (2014, August). Novel bacteriocins from lactic acid bacteria (LAB): various structures and applications. In Microbial cell factories (Vol. 13, No. 1, p. S3). BioMed Central. http://dx.doi.org/10.1186/1475-2859-13-S1-S3

Rios Colombo, N. S., Chalón, M. C., Navarro, S. A., \& Bellomio, A. (2018), Pediocin-like bacteriocins: new perspectives on mechanism of action and immunity. Current Genetics, 64(2), 345-351. http://dx.doi.org/10.1007/s00294017-0757-9

Rodríguez, J. M., Martínez, M. I., \& Kok, J. (2002). Pediocin PA-1, a widespectrum bacteriocin from lactic acid bacteria. Critical Reviews in Food Science and Nutrition, 42(2), 91-121. http://dx.doi.org/10.1080/10408690290825475

Sharma, G., Dang, S., Gupta, S., \& Gabrani, R. (2018). Antibacterial Activity, Cytotoxicity, and the mechanism of action of bacteriocin from Bacillus subtilis GAS101. Medical Principles and Practice, 27(2), 186-192. http://dx.doi.org/10.1159/000487306

Sharma, G., Raturi, K., Dang, S., Gupta, S., \& Gabrani, R. (2014). Combinatorial antimicrobial effect of curcumin with selected phytochemicals on Staphylococcus epidermidis. Journal of Asian Natural Products Research, 16(5), 535541. http://dx.doi.org/10.1080/10286020.2014.911289

Singh, P. K., Sharma, S., Kumari, A., \& Korpole, S. (2014). A non-pediocin low molecular weight antimicrobial peptide produced by Pediococcus pentosaceus strain IE-3 shows increased activity under reducing environment. BMC Microbiology, 14(1), 226. http://dx.doi.org/10.1186/s12866-014-0226-2

Yang, E., Fan, L., Jiang, Y., Doucette, C., \& Fillmore, S. (2012). Antimicrobial activity of bacteriocin-producing lactic acid bacteria isolated from cheeses and yogurts. Amb Express, 2(1), 48. http://dx.doi.org/10.1186/2191-0855-2-48

Yang, S.C., Lin, C.H., Sung, C.T., Fang, J.Y. (2014). Antibacterial activities of bacteriocins: application in foods and pharmaceuticals. Frontiers in Microbiology, 5:241. http://dx.doi.org/10.3389/fmicb.2014.00241 